\title{
PENGARUH MODEL PEMBELAJARAN CONCEPT ATTAINMENT TERHADAP KEMAMPUAN KOMUNIKASI DAN PEMAHAMAN KONSEP SISWA PADA MATERI SISTEM REPRODUKSI
}

\section{Influence of Learning Model Concept Attainment of the Communication Skills and Comprehension of Concept Students on the Reproductive System}

Yulilina Retno, Rusdi, Amalia

Pendidikan Biologi Fakultas MIPA Universitas Negeri Jakarta

Email: rusdi@unj.ac.id

\begin{abstract}
Students need to have one of the science process skills in learning which is communication skill. Based on observation it was known that not every student had the same communication capabilities, both in oral and written. This is due to lack of student's understanding about the concept of the material which being studied. Application of Concept Attainment learning model was expected to train students how to construct concepts on their own and be able to express it verbally. This study was aimed to determine the influence of the Concept Attainment learning model to communication skills and student's understanding of Reproductive System material concept. This research was conducted in SMA Negeri 16 Jakarta on May 2015. This research used quasi-experimental method. The sample were 30 students each in the experimental class and control class by using simple random sampling. The instrument for this research was a written communication skills post test, understanding of concepts post test, and the observation of verbal ability. The analysis prerequisite test was the test of normality with the Kolmogorov-Smirnov and homogeneity test with F test. Based on the calculations, the data were normally distributed and homogeneous. Hypothesis test using the test results showed that Ho was rejected at $\alpha 0.05$. It means that there was an influence of Concept Attainment learning model of the communication skills and student's understanding concept on Reproductive System.
\end{abstract}

Keywords : Concept Attainment, Communication skills, Comprehension of the concept

\section{PENDAHULUAN}

Proses belajar mengajar merupakan suatu kegiatan interaksi antara guru dengan siswa serta komunikasi timbal balik dalam keadaan edukatif untuk mencapai suatu tujuan belajar. Dalam pembelajaran, tidak hanya hasil belajar yang perlu diukur namun juga kemam-puan komunikasi siswa seperti menyam-paikan gagasan, ide atau pendapat, menarik kesimpulan berdasarkan konsep yang telah mereka pahami, serta pada saat membaca atau menginterpresentasikan tabel, gambar, bagan, dan diagram.

Menurut Dewi (2008), keterampilan mengkomunikasikan merupakan salah satu keterampilan proses sains yang perlu dimiliki oleh siswa, dalam penelitian Nugroho, dkk (2009) menyatakan keterampilan proses sains dapat mening-katkan pemahaman dan aktivitas siswa dalam pembelajaran. 
Berdasarkan hasil observasi, rendah-nya kemampuan komunikasi dan pema-haman konsep siswa disebabkan oleh proses belajar mengajar yang kurang melibatkan siswa secara langsung. Guru perlu melatih kemampuan berkomunikasi siswa, salah satu upaya yaitu dengan menerapkan model pembelajaran yang inovatif, kreatif, dan menyenangkan namun memungkinkan membantu siswa untuk mencapai pemahaman konsep dan mendapat pengalaman belajar secara langsung serta membangun sendiri pengetahuan untuk dikomunikasikan baik secara tertulis maupun lisan dalam melakukan eksplorasi materi dan memberikan kesempatan untuk berdiskusi (Rustaman, 2005).

Joyce, Weil dan Calhoun (2012) mendeskripsikan empat kategori model belajar, salah satunya kelompok pengo-lahan informasi (information processing family) yang termasuk di dalamnya yaitu model pembelajaran concept attainment.

Concept attainment merupakan model pembelajaran yang mendukung pengetahuan konseptual siswa dalam pendefinisian konsep dan kemampuan menggambarkan komponen dari konsep. Model pem-belajaran ini mula-mula didesain oleh Bruce yang didasarkan pada hasil riset Jerome Bruner dengan maksud untuk mengembangkan konsep dan mengana-lisisnya.

Bruner, Goodnow, dan Austin dalam Handayani (2014) menyatakan bahwa model concept attainment sengaja diran-cang untuk membantu para siswa mem-bentuk konsep-konsep dengan kemam-puannya sendiri, sehingga memberi ke-mudahan bagi siswa mempelajari konsep tersebut dengan cara yang lebih efektif dan dapat mengungkapkannya secara lisan.

Berdasarkan penelitian Harjono (2012), pengembangan perangkat pembelajaran model concept attainment untuk meningkatkan kemampuan komunikasi dinyatakan valid, praktis, dan efektif, dengan demikian kemampuan komunikasi dan pemahaman konsep siswa pada materi Sistem Reproduksi menjadi lebih baik.

Untuk itu, dilakukan penelitian yang terkait dengan kemampuan komunikasi dan pemahaman konsep siswa dengan menerapkan model pembelajaran concept attainment.

\section{METODELOGI PENELITIAN}

Penelitian ini menggunakan metode kuasi eksperimen. Variabel bebas pada penelitian ini adalah model pembelajaran concept attainment, sedangkan variabel terikat dalam penelitian ini adalah kemampuan komunikasi dan pemahaman konsep siswa pada materi Sistem Reproduksi.

\section{METODE}

Metode yang digunakan dalam penelitian ini yaitu menggunakan metode kuasi eksperimen. Sampel yang digunakan pada penelitian ini adalah masing-masing 30 siswa untuk kelas eksperimen dan kontrol yang ditentukan dengan cara simple random sampling.

\section{WAKTU DAN TEMPAT}

Penelitian ini dilaksanakan di SMA Negeri 16 Jakarta, pada bulan Mei 2016. 


\section{HASIL PENELITIAN}

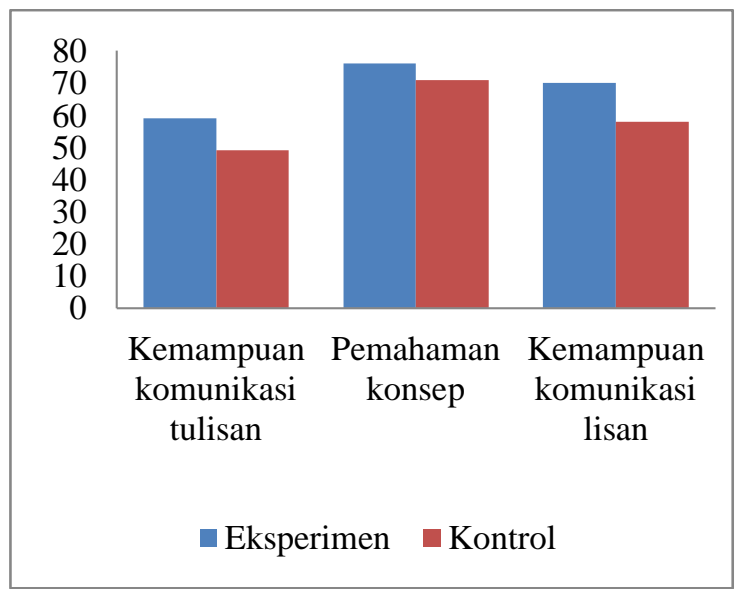

Gambar 1. Perbandingan Nilai Rata-rata Kelas Eksperimen Dan Kelas Kontrol

Tabel 1. Hasil uji t tes kemampuan komunikasi

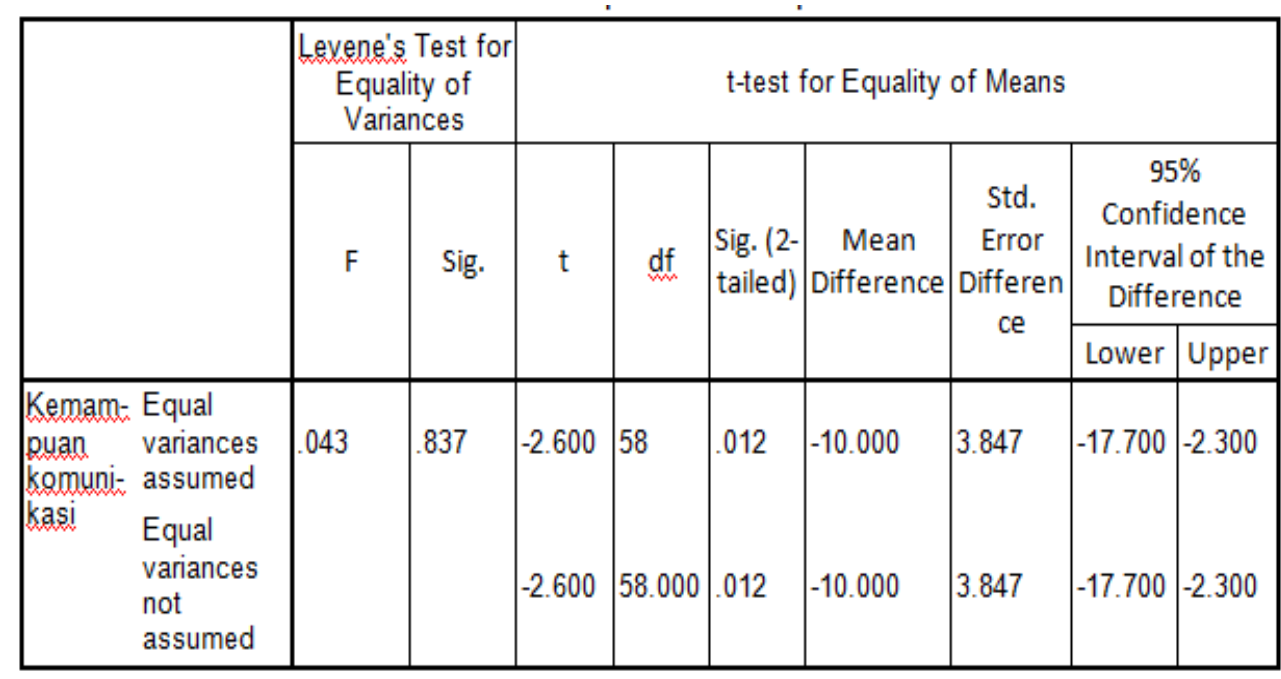

Tabel 2. Hasil uji t tes pemahaman konsep

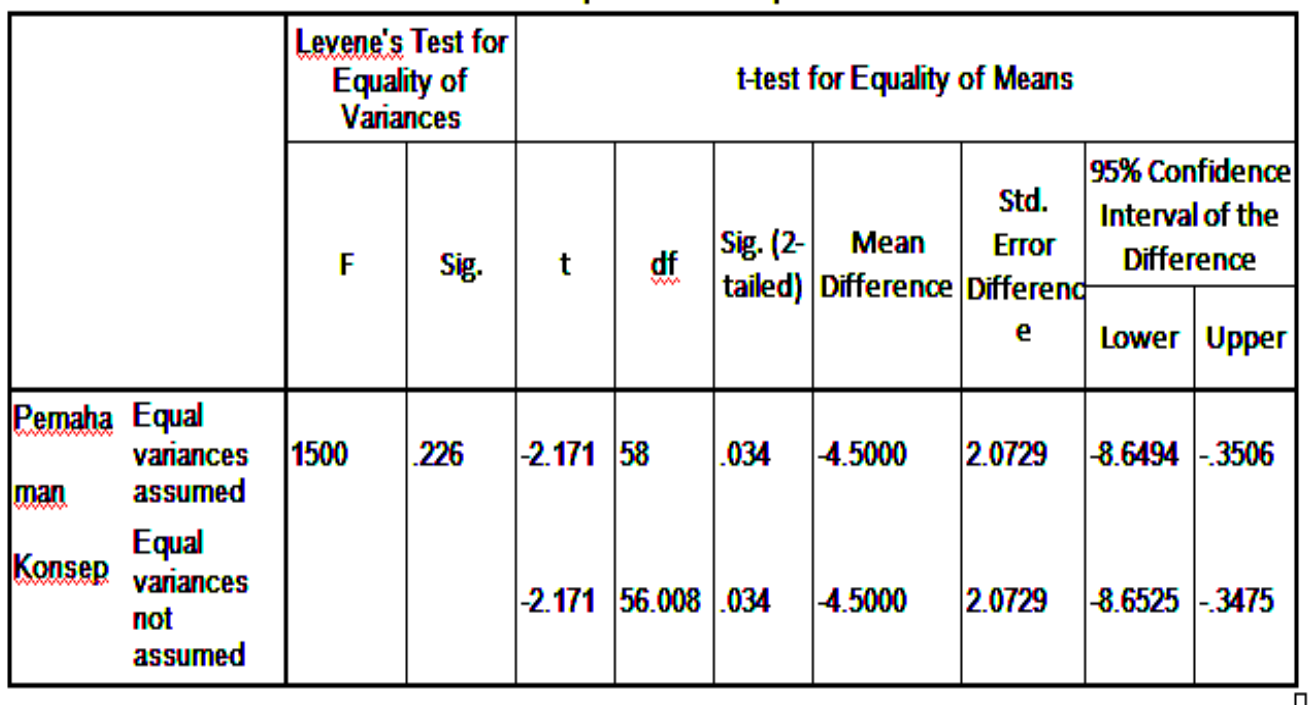




\section{PEMBAHASAN}

Berdasarkan hasil analisis dapat di-ketahui bahwa terdapat pengaruh model pembelajaran concept attainment terha-dap kemampuan komunkasi dan pema-haman konsep siswa pada materi sistem reproduksi. Siswa yang menggunakan model pembelajaran concept attainment memiliki nilai lebih tinggi dibanding siswa yang menggunakan model pem-belajaran STAD. Hal ini sesuai dengan yang dikemukakan oleh Nurjanah (2009) bahwa siswa yang diberi pembelajaran dengan concept attainment mempunyai nilai yang lebih baik dibandingkan siswa dengan pembelajaran STAD.

Kegiatan siswa pada pembelajaran dengan concept attainment dilibatkan secara aktif dalam merancang sebuah konsep dari contoh-contoh konseptual berupa gambar organ reproduksi pria dan wanita, gambar fertilisasi, diagram hor-mon menstruasi, maupun bagan gameto-genesis yang telah disajikan oleh guru. Siswa lebih banyak melakukan kegiatan secara mandiri dan didorong untuk men-capai konsep yang benar dan mampu mengklarifikasi ide-ide dalam mencer-mati aspek-aspek dari sebuah konsep, sehingga guru hanya berperan sebagai pembimbing dan fasilitator belajar (Winasmaji, 2011).

Kemampuan komunikasi siswa pada kelas eksperimen memiliki nilai lebih baik dari pada kelas kontrol. Dalam kegiatan pembelajaran siswa mampu terlibat secara aktif dalam berkomunikasi seperti me-nyampaikan atau menerima gagasan dan ide baik secara lisan maupun tulisan.

Kemampuan komunikasi lisan siswa dinilai oleh tiga observer yang merupakan mahasiswa keguruan yang telah mengikuti praktek kegiatan mengajar. Pada kelas eksperimen, siswa lebih banyak mencapai indikator yang telah ditetapkan diantaranya menyampaikan pendapat secara logis, memertahankan pendapat dengan alasan yang jelas, pendapat dijelaskan secara logis dan sistematis, membaca grafik, tabel, gambar atau diagram yang disajikan dengan benar, dan menganalisis grafik, tabel, gambar, atau diagram yang disajikan dengan benar (Rustaman, 2005).

Pada kemampuan tulisan siswa dapat menyajikan hasil pengamatan berupa tabel perbedaan spermatogenesis dan oogenesis, bagan organ reproduksi, maupun grafik siklus menstruasi secara baik. Hal ini sesuai dengan yang dikemukakan oleh Eggen dan Kauchak (2012) bahwa model pembelajaran concept attainment dapat melatih siswa mengembangkan dan menguatkan pemahaman siswa mengenai konsep dan mempraktekkan kemampuan berpikirnya.

Tes pemahaman konsep yang diberi-kan pada siswa berupa 40 soal pilihan ganda meliputi tujuh aspek pemahaman konsep diantaranya menginterpretasikan, menyontohkan, mengklasifikasikan, me-rangkum, menyimpulkan, membanding-kan dan menjelaskan. Berdasarkan hasil tes pemahaman konsep Sistem Repro-duksi pada kelas eksperimen, nilai rata-rata siswa lebih tinggi dari pada kelas kontrol. Kemampuan siswa dalam men-jelaskan konsep dengan kata-kata sendiri mengenai suatu informasi terkait materi Sistem Repro-duksi yang relevan, benar dan ilmiah menandakan siswa memiliki pemahaman terhadap konsep pada materi Sistem Reproduksi (Hermawati, 2012). 


\section{DAFTAR PUSTAKA}

University of British Columbia co economics, 32(3), 375-380.

Dewi, S. 2008. Keterampilan Proses Sains. Bandung: Tinta Mas

Eggen, Paul dan Don Kauchak. 2012. Strategi dan Model Pembelajaran. Jakarta: Indeks

Handayani, Suciati, Baskoro. 2014. Pembelajaran Biologi Dengan Concept Attainment Model Menggunakan Teknik Vee Diagram Dan Concept Map Ditinjau Dari Kemampuan Berpikir Kritis Dan Penalaran Ilmiah. Jurnal Inkuiri, 3 (2): 16-27

Harjono, Sri. 2012. Model Pembelajaran Concept Attainment Meningkatkan Kemampuan Komunikasi Matematik. Journal of Educational Research and Evaluation, 1 (2): 72-83

Hermawati, Ni Wayan Manik. 2012. Pengaruh Model Pembelajaran Inkuiri Terhadap Penguasaan Konsep Biologi Dan Sikap Ilmiah Siswa Sma Ditinjau Dari Minat Belajar Siswa. Jurnal Penelitian Pascasarjana UNDIKHSA, 2(2): 21-24

Joyce, B dan Weil, M. 2009. Models of Teaching/Model-Model Pengajaran,[Edisi Kedelapan]. Jakarta: Pustaka Pelajar

Nugroho, Hartono, Edi. 2009. Penerapan Pembelajaran Kooperatif Tipe Stad Berorientasi Keterampilan Proses. Jurnal Pendidikan Fisika Indonesia 5: 108-112 Nurjanah. 2009. Penerapan Model Concept Attainment Terhadap Hasil Belajar Siswa Pada Materi Metabolisme. Thesis, Universitas Sebelas Maret Surakarta

Rustaman, N. 2005. Strategi Belajar Mengajar Biologi. Malang: UM PRESS

Winasmaji, Praja. 2011. Pengembangan Perangkat Pebelajaran Matematika Dengan Model Concept Attainment Berbantuan Cd Interkatif Pada Materi Segitiga Kelas Vii. Jurnal Penelitian Pascasarjana, 1 (2): 119-126 